THREE MYTHS ABOUT FEDERAL REGULATION

Patrick A. McLaughlin

Casey B. Mulligan

Working Paper 27233

http://www.nber.org/papers/w27233

\author{
NATIONAL BUREAU OF ECONOMIC RESEARCH \\ 1050 Massachusetts Avenue \\ Cambridge, MA 02138 \\ May 2020
}

We appreciate insights from, discussions with, and reports by the White House Council of Economic Advisers. Blake Hoarty and Hayden Warlick provided valuable research assistance. We also thank Christina Behe and Nita Ghei for providing useful feedback on an early draft. The views expressed herein are those of the authors and do not necessarily reflect the views of the National Bureau of Economic Research.

NBER working papers are circulated for discussion and comment purposes. They have not been peer-reviewed or been subject to the review by the NBER Board of Directors that accompanies official NBER publications.

(C) 2020 by Patrick A. McLaughlin and Casey B. Mulligan. All rights reserved. Short sections of text, not to exceed two paragraphs, may be quoted without explicit permission provided that full credit, including $\odot$ notice, is given to the source. 
Three Myths about Federal Regulation

Patrick A. McLaughlin and Casey B. Mulligan

NBER Working Paper No. 27233

May 2020

JEL No. K23,L51,Q58

\begin{abstract}
$\underline{\text { ABSTRACT }}$
Despite evidence to the contrary, three common myths persist about federal regulations. The first myth is that many regulations concern the environment, but in fact only a small minority of regulations are environmental. The second myth is that most regulations contain quantitative estimates of costs or benefits. However, these quantitative estimates appear rarely in published rules, contradicting the impression given by executive orders and Office of Management and Budget guidance, which require cost-benefit analysis (CBA) and clearly articulate sound economic principles for conducting CBA. Environmental rules have relatively higher-quality CBAs, at least by the low standards of other federal rules. The third myth, which is particularly relevant to the historic regulations promulgated during the COVID-19 pandemic, is the misperception that regulatory costs are primarily clerical, rather than opportunity or resource costs. If technocrats have triumphed in the regulatory arena, their victory has not been earned by the merits of their analysis.
\end{abstract}

Patrick A. McLaughlin

Mercatus Center at

George Mason University

3434 Washington Blvd

Arlington, VA 22201

pmclaughlin@mercatus.gmu.edu

Casey B. Mulligan

University of Chicago

Department of Economics

1126 East 59th Street

Chicago, IL 60637

and NBER

c-mulligan@uchicago.edu

A data appendix is available at http://www.nber.org/data-appendix/w27233 
Regulation is one of the hardest concepts to grasp in the world of policy, largely because its vast breadth and depth defy comprehension. Regulatory experts have not settled on a single way to quantify the body of regulations on the books at any given point in time. Nonetheless, as of January 3, 2020, the Code of Federal Regulations contains over 103 million words of rules promulgated by more than 100 agencies, which would take a fulltime worker reading at 250 words per minute more than 3 years to read. ${ }^{1}$

Federal regulation is broadly misunderstood, even by the "regulatory czars" who have oversight. The misunderstandings can be summarized as three mutually reinforcing myths:

1) The first myth is about the composition of the flow of regulation (and deregulation) - that regulations address mostly environmental concerns. We find instead that only a small fraction of regulation is environmental. Economic and social regulations are far more common. Our data suggest that the costs of health regulation have exceeded the costs of environmental regulation over the past couple of decades, and this observation does not even begin to count the costs of regulations in 2020 intended to combat the coronavirus pandemic.

2) The second myth is that regulators offer reasonable justifications and quantitative evidence for regulations. Despite executive orders and Office of Management and Budget $(\mathrm{OMB})$ guidance requiring cost-benefit analysis (CBA) of new regulations, the typical justifications and cost assessments of nonenvironmental regulations are seriously lacking.

\footnotetext{
${ }^{1}$ The exact number of regulatory agencies is difficult to pin down. The Sourcebook of United States Executive Agencies offers estimates ranging from 118 to more than 600: "For example, FOIA.gov lists 118 separate executive agencies that comply with the Freedom of Information Act requirements imposed on every federal agency. This appears to be on the conservative end of the range of possible agency definitions. The United States Government Manual lists 305 unique or subcomponent units as agencies. An even more inclusive listing comes from USA.gov, which lists over 600 government departments and agencies." Jennifer L. Selin and David E. Lewis, Sourcebook of United States Executive Agencies, 2nd ed. (Washington, DC: Administrative Conference of the United States, 2018), 12.
} 
3) The third myth is about the nature of the costs imposed by regulations on households and businesses - that the bulk of the costs are clerical. Although many regulations create nontrivial paperwork and clerical costs, the vast majority of regulation costs are economic distortions.

There may also be myths about the benefits of regulation. However, we expect that agencies and Congress are more aware of these benefits because something motivated the regulators to promulgate the regulations in the first place. The costs of regulation are less proximate to the regulators themselves. We leave comprehensive analysis of benefits for future research. Readers may also be interested in the net benefit calculations prepared by the Council of Economic Advisers (CEA), which quantify a wide range of regulatory benefits, including "consumer data privacy, environmental protection, fuel savings, and reductions in uncompensated healthcare."2

\section{Regulatory Background}

The constantly changing alphabet soup of federal agencies leaves even experts confused about how many agencies exist and which ones issue regulations. A good working definition of a regulation, which we take to be a government intervention that requires or prohibits some action or activity, can help understand regulations' origins. Under that definition, federal regulations originate in all three branches of government, as we explain in this section.

\section{Congress}

Congress can write and pass bills that, if signed into law by the president or passed over a veto, all Americans must obey. In writing laws, Congress can delegate authority to the executive branch, which includes executive agencies whose heads sit on the president's cabinet as well as independent agencies such as the Federal Communications Commission or the Federal Reserve System. The delegation of lawmaking authority can be explicit, as

\footnotetext{
${ }^{2}$ Council of Economic Advisers, The Economic Effects of Federal Deregulation since January 2017: An Interim Report, June 2019; White House, Economic Report of the President Together with the Annual Report of the Council of Economic Advisers, February 2020, 134.
} 
with the House Medicare for All bills directing that "the Secretary [of Health and Human Services] shall pay, from amounts made available for capital expenditures ... such sums determined appropriate by the Secretary to providers." ${ }^{3}$ Congress can also delegate implicitly by writing its bills with vague terms that executive branch agencies or federal courts must further interpret in order to make them operational. Take the 1963 Clean Air Act, which, as subsequently amended by Congress, requires the EPA to establish standards "applicable to the emission of any air pollutant" from motor vehicles. ${ }^{4}$ The act itself does not say whether the greenhouse gases (such as carbon dioxide) causing climate change are an "air pollutant." The EPA ultimately decided that they are. The Supreme Court affirmed the EPA's decision when it concluded that "greenhouse gases fit well within the Clean Air Act's capacious definition of 'air pollutant.",

\section{Federal Agencies}

Most regulations are created when regulatory agencies publish final rules, which explain changes to the text of existing regulations. ${ }^{6}$ As such, final rules can be conceived of as regulatory "flows." New rules are published, by both executive agencies and independent agencies, in the Federal Register and indicate the parts of the Code of Federal Regulations (CFR) to be changed. Rules can add text to the CFR, revise it, or remove it. ${ }^{7}$ The CFR is therefore a stock of regulation. ${ }^{8}$ As published in the Federal Register, new rules also include agency motivation, analysis of budgetary and economic impact, and summary of public comments that are not part of the CFR.

\footnotetext{
${ }^{3}$ Medicare for All Act of 2019, H.R. 1384, 116th Cong. (2019).

${ }^{4}$ Clean Air Act of 1963, 42 U.S.C. $§ 7521(a)(1)(2013)$.

${ }^{5}$ Massachusetts v. EPA, 549 U.S. 497, 532 (2007).

${ }^{6}$ Most agencies are considered part of the executive branch, although a handful of independent agencies defy such simple classification. Nonetheless, all agencies - executive or independentcreate regulations in the same way, as prescribed by the Administrative Procedure Act.

${ }^{7}$ Examples of these are 76 Fed. Reg. 26547 (showing additions and revisions to the text of the CFR) and 82 Fed. Reg. 29237 (removing regulations that were invalidated by Congress and the president). Adding text to the CFR is not necessarily the same as restricting the choices of households or businesses. Agency guidance documents can also be considered flows of regulation, although they are not part of the CFR.

${ }^{8}$ Sections of the CFR refer back to the pages of the Federal Register that created or modified their text.
} 


\section{Judiciary}

Federal regulation sometimes originates in federal courts on a case-by-case basis, as with some regulation of competition, without rules or guidance. Case-specific regulations can become a permanent part of the regulatory landscape, especially if they are affirmed by federal courts. ${ }^{9}$

\section{Data on the Stocks and Flows of Regulations}

To the extent that the federal government provides summary measures of the flow of regulation, these summary measures cover only the rules promulgated by the executive agencies. That is, they exclude guidance documents published by any agency, rules published by independent agencies, and statutes or court decisions that are not reflected in agency rulemaking. And the information produced by executive agencies from that subset of regulatory actions is fairly narrow - for example, most new rules are not accompanied by quantitative estimates of benefits and costs.

Recent years have witnessed the advent of independent academic research projects that attempt to fill the data gap about regulation. The most prominent of these is the RegData Project. Launched in 2012 with a working paper by Omar Al-Ubaydli and Patrick A. McLaughlin, RegData is both a methodology and a database. The RegData methodology entails using text analysis and machine-learning algorithms to parse and quantify the CFR. Several dimensions, or features, of federal regulations have been quantified over the course of the ongoing RegData Project, including the quantity of regulatory restrictions contained in regulations and the relevance of those restrictions to the various sectors and industries that make up the US economy. The resulting data have been made freely available to the public at QuantGov.org. ${ }^{10}$

The two primary metrics in the RegData database are restrictions and industry relevance. Restrictions is a cardinal proxy of the number of regulatory restrictions contained in regulatory text, devised by counting select words and phrases, such as shall

\footnotetext{
${ }^{9}$ For example, Standard Oil Co. of New Jersey v. United States set the precedent for subsequent antitrust regulation. 221 U.S. 1, 31 S. Ct. 502 (1911).

${ }^{10}$ Patrick A. McLaughlin and Oliver Sherouse, RegData US 3.1 Annual (dataset), QuantGov, Mercatus Center at George Mason University, Arlington, VA, 2018, https://quantgov.org/regdataus/.
} 
or must, that are typically used in legal language to create binding obligations or prohibitions. The database also includes a secondary measure of volume - the total word counts - as an alternative measure of the volume of regulation over time.

The second key variable in RegData is industry relevance, representing estimates of the relevance of the text of a regulation to the different sectors and industries in the economy. RegData utilizes the industry definitions in the North American Industry Classification System (NAICS), which categorizes all economic activity into different industries. RegData uses machine-learning algorithms to assess the probability that a unit of regulatory text targets a specific NAICS industry. This assessment requires two steps. First, the program "learns" what words, phrases, and other features can best identify when a unit of text is relevant to a specific industry by analyzing our compilation of training documents. Training documents are documents that are known to be relevant to one or more explicitly named industries. Over the course of the RegData project, we have gathered tens of thousands of training documents from publications in the Federal Register that name the NAICS codes affected by rulemakings.

Second, some simple calculations permit the combination of restrictions and industry relevance into a single variable, industry restrictions, which is an estimate of the number of restrictions that are relevant to a particular industry or set of industries in one or more regulations. ${ }^{11}$ The advent of an industry-specific metric of regulation that is comprehensive (i.e., inclusive of all federal regulations that are in effect in each year), replicable, and transparent has created paths to performing economic research on regulation in ways that were previously infeasible. All of these metrics-restrictions, industry relevance, and industry restrictions - can be cross-tabulated with regulatory agency because RegData encodes the CFR's attribution (in its various tables of contents) of each part of the CFR with an agency. ${ }^{12}$

Other approaches have sampled the flow of regulations. These include Jerry Ellig's "regulatory report cards" and analysis by the Competitive Enterprise Institute's Clyde

\footnotetext{
${ }^{11}$ For further discussion and examples, see Omar Al-Ubaydli and Patrick A. McLaughlin, "RegData: A Numerical Database on Industry-Specific Regulations for All United States Industries and Federal Regulations, 1997-2012," Regulation \& Governance 11, no. 1 (2017): 109-23.

${ }^{12}$ Occasionally agencies engage in joint rulemaking, in which case each restrictive word in the shared CFR part would count toward each agency. For the purposes of aggregating across agencies, the restrictive word would count only once.
} 
Wayne Crews. ${ }^{13}$ The CEA sampled 21 regulatory and deregulatory actions from five broad categories based on indicators of importance to the public. ${ }^{14}$ The Federal regulatory budget itself, which dates back to fiscal year 2017, is a fiscal year sample of rules from executive agencies that includes rule-specific cost estimates. ${ }^{15}$

\section{Myth \#1: Most Regulation is Environmental}

\section{Estimates from RegData and the Federal Register}

The first myth about regulation is that most regulation is environmental. This commonly repeated myth inaccurately equates deregulation with polluted air and water. In fact, only 14 percent of all economically significant federal rules issued between 2000 and 2016 came from the three major environmental agencies: the EPA, the Department of

\footnotetext{
${ }^{13}$ Jerry Ellig, "Evaluating the Quality and Use of Regulatory Impact Analysis: The Mercatus Center's Regulatory Report Card, 2008-2013" (Mercatus Working Paper, Mercatus Center at George Mason University, Arlington, VA, July 2016); Clyde Wayne Crews, "Less Than 1 Percent of Federal Regulations Get Cost-Benefit Analysis," Competitive Enterprise Institute, November 17, 2015, https://cei.org/blog/less-1-percent-federal-regulations-get-cost-benefitanalysis.

${ }^{14}$ Council of Economic Advisers, The Economic Effects of Federal Deregulation since January 2017; White House, Economic Report of the President Together with the Annual Report of the Council of Economic Advisers, February 2020. The CEA's categories are (1) statutes, (2) the 16 federal rules or guidance overturned under the Congressional Review Act (CRA) since January 2017, (3) rules in the fiscal year 2018 and 2019 regulatory budgets, (4) agency guidance documents, and (5) rulemaking by independent agencies. Solely because it selected from the years 2017-2019 according to public attention, the CEA's sample comprises entirely deregulatory actions; the regulatory actions in the regulatory budget received few public comments.

15 "Economically significant" regulations are those that have costs or other economic effects that are estimated to exceed $\$ 100$ million annually or that meet other criteria specified in Executive Order 12866, which governs regulatory analysis and review for executive branch agencies. Economically significant rules are part of the regulatory budget, unless they are "transfer rules," which "cause only income transfers between taxpayers and program beneficiaries." Office of Management and Budget, "Guidance Implementing Executive Order 13771, Titled 'Reducing Regulation and Controlling Regulatory Costs"' (M-17-21, Executive Office of the President, Washington, DC, April 5, 2017), 6. The budget also includes a number of other substantive, nonsignificant rules selected by the regulating agency. We suspect that many of those rules were selected for regulatory budgeting with the intention of increasing the agency count of deregulatory actions.
} 
Interior (DOI), and the Nuclear Regulatory Commission (NRC). ${ }^{16}$ These results are shown in the top panel of table 1 .

Table 1. Three Methods of Quantifying New Regulation, 2000-2016

\begin{tabular}{lrc}
\hline \multicolumn{1}{c}{ Quantification Method } & Count or amount & Share \\
\hline Economically significant rules ("count or amount" & & \\
= number of rules) & 926 & 1.00 \\
All executive agencies & 296 & 0.32 \\
HHS & 796 & 0.86 \\
Nonenvironmental & 130 & 0.14 \\
Environmental & 214 & 1.00 \\
RegData: restrictive words ("count or amount" = number of restrictive words in thousands) \\
All agencies & 18 & 0.08 \\
HHS & 141 & 0.66 \\
Nonenvironmental & 72 & 0.34 \\
Environmental & & \\
CEA sample of 21 regs later removed ("count or amount" = \$ billions) & 276 & 1.00 \\
All agencies & 91 & 0.33 \\
HHS (4) & 219 & 0.79 \\
Nonenvironmental (18) & 57 & 0.21 \\
Environmental (3) & &
\end{tabular}

Note: Ninety-eight percent of the "count or amount" of environmental regulations in the CEA sample is from a single rule.

The small share of environmental regulation is also confirmed by RegData statistics, which also include the rules that are not designated as economically significant. Table 1 shows how essentially two-thirds of the 2000-2016 increase in restrictive words $(141,000$ out of 214,000$)$ were made by agencies with primarily nonenvironmental missions. Although not shown in the table, the stock of restrictive words as of 2017 is also illustrative: it was about 1.1 million overall and about 238,000 for the environmental agencies. In other words, 79 percent of the stock of regulation is nonenvironmental.

The Department of Health and Human Services (HHS) is the single largest promulgator of economically significant regulations between 2000 and 2016, outpacing

\footnotetext{
${ }^{16}$ This rule count, combined by the George Washington University Regulatory Studies Center, is for executive agencies only. The NRC is the only significant independent agency with an environmental mission.
} 
EPA by more than three to one. While contributing many words, HHS contributes less to the increase in restrictive words. A potential reason for its large contribution to economically significant rules may be the large size of HHS (its annual budget is more than $\$ 1$ trillion), given that one of the thresholds for economic significance is an absolute dollar amount. From this perspective, the number of rules may be a better indicator for comparing regulatory costs across agencies than the number of restrictive words. A second potential reason is that many important HHS rules have a duration of only one year, and therefore it issues multiple rules on the same topic, with new rules replacing old (hence, comparatively little increase the CFR stock of restrictive words). For the purposes of interagency comparisons, perhaps this results in exaggerating the importance of HHS. On the other hand, the fact that HHS does rulemaking so frequently may indicate a high level of detail and large scope with which it regulates.

Future interagency regulatory comparisons will include the period of the COVID19 pandemic, during which time HHS regulators were considering everything from rules for employers to approvals of new drugs and therapies. We expect that the updated comparisons will further debunk the first myth by showing that the economic impact of new federal health regulation far exceeds that of new environmental regulation.

\section{Examples Selected on the Basis of Public Attention}

Not all rules are equally important. Nor is each occurrence of "shall" or "must" in the CFR equally important. Ideally, we could use quantitative estimates of importance provided by the regulating agencies, but, as discussed in connection with the second myth, quantitative estimates are often absent, or they frequently obscure an economically important regulation. Instead we use the sample of 21 post-2016 deregulations selected by the CEA on the basis of attention from the public, ${ }^{17}$ as measured by number of comments submitted during the comment period of rulemaking and attention from Congress. These deregulations removed 21 regulations that were put in place between 2000 and 2016, so what the CEA reports as cost savings from deregulation can be taken as an estimate of the

\footnotetext{
${ }^{17}$ Council of Economic Advisers, The Economic Effects of Federal Deregulation since January 2017; White House, Economic Report of the President Together with the Annual Report of the Council of Economic Advisers, February 2020.
} 
costs created by their precursor regulations. The CEA sample is also interesting because, as a sample of "only" 21, it facilitates a discussion of specific regulations while at the same time capturing an important part of the totality of regulation.

For example, the fiscal year 2018 regulatory budget had more than 200 rules from the executive agencies, which are already selected on the basis of economic importance. Among the 10 rules from executive agencies with at least 100 comments, only one was environmental. The quantity of comments received on that one rule, known as the "Waste Prevention Rule" or "Venting and Flaring Rule," was wildly disproportionate with its costs and benefits. Because the regulation applies only to oil and gas operations on federal and tribal lands, whereas at least 80 percent of oil and gas operations are on private lands, the annualized cost savings from the deregulation was only about $\$ 0.3$ billion as compared to the CEA's estimate of an average of $\$ 4$ billion for the nine nonenvironmental rules. In other words, less than 1 percent of the cost savings from deregulation in that year's budget came from environmental deregulation.

To be more concrete, it helps to reflect on some of the deregulations that have received public attention. A 2018 rule letting consumers keep their short-term health insurance plans (pejoratively known as "junk" plans by those who disapprove of the plan designs) is an economic deregulation and does not pollute air or water. No pollution is created by ending a foreign drug company's monopoly on the sales of generic prescription drugs, as the FDA did in 2017 and 2018 by improving the process of approving generic drugs. ${ }^{18}$ The environment is not dirtier because university students are considered customers of the university rather than employees, as the National Labor Relations Board designated during the Obama administration. Removing regulatory barriers from the franchise way of doing business, as the Department of Labor and the National Labor Relations Board recently did, does not pollute air or water. All of these examples involve regulatory costs in the billions of dollars per year. ${ }^{19}$

The vehicle emissions rule will result in a large environmental share of the

\footnotetext{
${ }^{18}$ Council of Economic Advisers, The Administration's FDA Reforms and Reduced Biopharmaceutical Drug Prices, October 2018.

${ }^{19}$ Each of these examples is discussed in more detail in the regulatory chapters of the 2019 and 2020 Economic Reports of the President. White House, Economic Report of the President Together with the Annual Report of the Council of Economic Advisers, March 2019; White House, Economic Report of the President Together with the Annual Report of the Council of Economic Advisers, February 2020.
} 
regulatory budget for fiscal year 2020, although it is an exception that proves the rule. Estimates of the environmental costs of vehicle emissions from the Trump and the Obama administrations are in comparatively close agreement. The overwhelming difference between them is their assessments of the nonenvironmental economic costs. Figure 1 shows the components of benefits and costs as estimated by both administrations. They include private fuel savings, vehicle maintenance, and technology costs, to name a few. By both estimates, the environmental benefits are just a tiny sliver. The substantive disagreement is whether consumers can be trusted to assess the effect of vehicle choice on their families' fuel budgets. The Obama administration assumed that enough consumers lacked this skill that federal regulations were needed to protect them from their suboptimal vehicle choices.

\section{Figure 1. Environmental Benefits are Dwarfed in the Cost-Benefit Analysis of Emissions Rules}

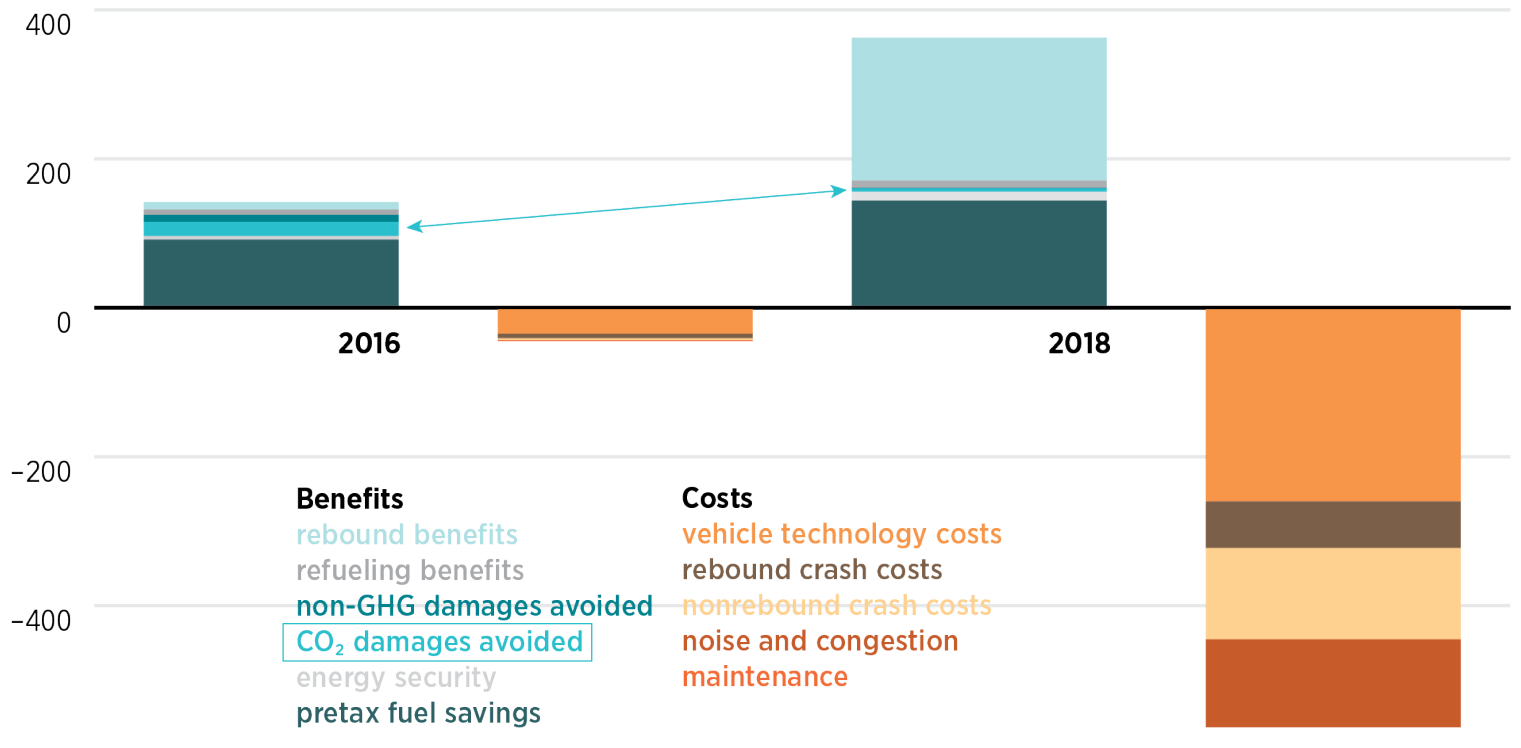

$-600$

Note: CBAs from 2016 and 2018 are from the Obama and Trump administrations, respectively. A comparison of these datasets was originally made by Antonio M. Bento et al., "Flawed Analyses of US Auto Fuel Economy Standards," Science 362, no. 6419 (2018): 1119-21. GHG = greenhouse gas.

Sources: EPA, National Highway Transit Safety Administration, and California Air Resources Board, Draft Technical Assessment Report: Midterm Evaluation of Light-Duty Vehicle Greenhous Gas Emission Standards and Corporate Average Fuel Economy Standards for Model Years 2022-2025, July 2016, table 
12.82; The Safer Affordable Fuel-Efficient (SAFE) Vehicles Rule for Model Years 2021-2026 Passenger Cars and Light Trucks, 83 Fed. Reg. 42986, table VII-51 (proposed August 24, 2018) (to be codified at 49 C.F.R. pts. 523, 531, 533, 536, and 537, and at 40 C.F.R. pts. 85 and 86 ).

The bottom panel of table 1 accumulates the CEA's results. The aggregate annual regulatory costs of the 21 selected regulations implemented in the 2000-2016 period are estimated to be $\$ 276$ billion. Seventy-nine percent of these costs are nonenvironmental. In contrast, HHS regulations alone account for a third of the regulatory costs. This interagency distribution of regulatory costs is remarkably similar to the distribution obtained merely by counting economically significant rules (top panel of table 1).

\section{Myth \#2: Regulation Is Smart and Evidence Based}

The second myth is that federal regulation is smart and evidence based. Professor and former federal regulatory czar Cass Sunstein declared a "triumph of the technocrats" in a "cost-benefit revolution [that] requires regulators to demonstrate a genuine need for government action ... weaken[ing] the hold of interest groups, popular opinion, anecdotes, and intuitions." ${ }^{20}$ Based on his assessment that federal regulators capably balance costs and benefits, Sunstein concludes that any additional constraints on regulators, such as a regulatory budget, "are hard to defend." 21 The 2012 Economic Report of the President describes a regulatory process that purportedly includes "careful analysis of costs and benefits, both before and after regulatory action, including an informed public discussion." 22

Good analysis is certainly an important input to smart regulation. ${ }^{23}$ As regulatory expert Jerry Ellig puts it, "[Good] regulation ... means regulation that solves a significant

${ }^{20}$ Cass R. Sunstein, The Cost-Benefit Revolution (Cambridge, MA: MIT Press, 2018), xi, 3.

${ }^{21}$ Sunstein, The Cost-Benefit Revolution, 20.

${ }^{22}$ White House, Economic Report of the President Together with the Annual Report of the Council of Economic Advisers, February 2012.

${ }^{23}$ Indeed, good analysis is such a vital component to smart regulation that OMB published a circular describing how a good economic analysis of a proposed regulation should be executed. See Office of Management and Budget, Circular A-4, September 17, 2003. 
problem at a reasonable cost. To know whether a regulation solves a significant problem at a reasonable cost, the regulatory agency needs to know whether a significant problem exists, the root cause of the problem, alternative solutions that address the root cause, the effectiveness of each alternative in solving the problem, the benefits to society of each alternative, and the costs to society of each alternative. This is the information that a complete regulatory impact analysis (RIA) provides." ${ }^{24}$

Unfortunately, the actual record of agency analysis of nonenvironmental regulations is quite the opposite. Clyde Wayne Crews's study of the 53,838 federal rules finalized between 2001 and 2014 finds that only 246 of them (less than one percent) quantified regulatory costs. Only 160 quantified benefits. A more recent analysis found that between 2007 and 2016, only 137 of the 36,255 final rules ( 0.4 percent) had dollar estimates for both benefits and costs. ${ }^{25}$ Important regulations are often classified (whether strategically or by accident, we cannot say) as not "economically significant" and thereby exempt from analysis requirements. Another exemption is obtained by issuing "guidance" rather than formal rulemaking, although the Trump administration now requires guidance to be reviewed together with proposed rules.

More than 20 major rules per year are "transfer rules" and almost by definition underestimate costs by orders of magnitude, despite the fact that a more accurate estimate of costs could be obtained by "a simple multiplication operation." ${ }^{26}$ By definition, a transfer rule asserts its primary effect to be transferring a significant amount of income from one party to another rather than creating a significant aggregate cost. However, the assertion is questionable because transfers often "induce moral hazard or other inefficient behavior," ${ }^{27}$ especially when the transfer is to or from federal taxpayers, which is typical of federal transfer rules. OMB Circular A-94 has long guided agencies on how to quantify the marginal excess burden of transfers to and from federal taxpayers, but agencies have not adhered to the guidance. More recently, OMB sought public comment on more sternly requiring agencies to use multiplication to estimate the economic distortions created by

\footnotetext{
${ }^{24}$ Ellig, "Evaluating the Quality and Use of Regulatory Impact Analysis," 1.

${ }^{25}$ James Broughel, "More Information Needed on the Benefits and Costs of Regulations," The Bridge, August 22, 2018.

${ }^{26} \mathrm{OMB}$, "Marginal Excess Tax Burden as a Potential Cost under EO 13771," Regulations.gov, December 6, 2019, https://www.regulations.gov/document?D=OMB-2017-0002-0055.

${ }^{27} \mathrm{OMB}$, "Guidance Implementing Executive Order 13771," 6.
} 
transfers. $^{28}$

The Federal Communications Commission (FCC) under Tom Wheeler (2013-17) is an example of an agency that promulgated economically important regulations such as privacy mandates and "net neutrality" price regulations on business-to-business transactions without professional cost-benefit analysis. As a former publisher of the Wall Street Journal put it, "The White House and FCC acted on pure ideology. Cost-benefit analysis? What's that?" 29 The FCC's chief economist in 2014 described his agency's rules as "an economics-free zone" in which "a fair amount of the economics was wrong, unsupported, or irrelevant." 30 The CEA estimates that just two of the rules issued by the FCC in 2015 and 2016 had annual regulatory costs in the tens of billions of dollars. ${ }^{31}$

\section{Regulatory Costs are Underestimated by Orders of Magnitude}

An important example of underestimating regulatory costs was mentioned above: the 2016 prohibition of "junk" insurance plans. No cost was assessed for that rule because the rule was designated as not economically significant, but this designation is not supposed to be used unless there is no material adverse effect on any sector of the economy. It is absurd to deny any material adverse effect from a prohibition of a product that 2 million people would be purchasing (as estimated by the nonpartisan Congressional Budget Office). ${ }^{32}$ The CEA later estimated that the annual cost of this regulation was $\$ 13$ billion, which is 130 times the monetary threshold for economic significance.

The FDA's regulation of generic prescription drugs is another example. It had such a burdensome approval process for generic manufacturers that sometimes only one company was making a generic. A few lucky or well-connected companies were able to

\footnotetext{
${ }^{28}$ OMB, "Marginal Excess Tax Burden as a Potential Cost under EO 13771."

${ }^{29}$ L. Gordon Crovitz, “"Economics-Free' Obamanet,” Wall Street Journal, January 31, 2016.

${ }^{30}$ Crovitz, "'Economics-Free' Obamanet."

${ }^{31}$ White House, Economic Report of the President Together with the Annual Report of the Council of Economic Advisers, February 2020. It is worth noting that the FCC recently created an Office of Economics and Analytics to provide "analytical and quantitative support for rulemakings," among other things. The new office opened in December 2018, as described in Federal Communications Commission, "FCC Opens Office of Economics and Analytics," news release, December 11, 2018, https://docs.fcc.gov/public/attachments/DOC-355488A1.pdf. ${ }^{32}$ Congressional Budget Office, Federal Subsidies for Health Insurance Coverage for People under Age 65: 2018 to 2028, May 2018.
} 
sell a drug they did not invent at a price about as high as when the inventor had the monopoly. When the FDA put those procedures in place, no cost was assessed because they were promulgated as a "guidance" document exempt from the cost-assessment requirement. The CEA estimated that these barriers to entry were costing consumers tens of billions of dollars per year. ${ }^{33}$

As a third example, we note how the FDA has at times minimized or ignored the actual effects of its policies to avoid acknowledging them as regulatory costs. The FDA asserts that it intends its prescription-opioid policies (among others) to "actually result in a decrease in misuse and abuse, and their consequences, addiction, overdose and death, in the community." 34 The actual result, however, involves illicit markets, yet the FDA refuses to recognize that any illicit activity results from its policies, even retrospectively. One doctor stated at an FDA conference to evaluate the impact of the agency's opioid "reformulation" policy, “As FDA we don't have much control over Mexican cartels and the availability of low-cost heroin." ${ }^{35}$ Another, speaking on the same topic, said, "Don't try to measure things you can't control." ${ }^{36}$ Meanwhile, studies suggest that thousands of people overdose on heroin and fentanyl (these are illicitly manufactured opioids) as a result of the FDA's prescription policies that cause consumers to switch away from prescriptions and toward the illicitly manufactured opioids. ${ }^{37}$ We are not saying that the FDA should

\footnotetext{
${ }^{33}$ As further proof of the economic significance of the generic-drug entry barriers, take Teva Pharmaceutical, an Israeli company known as the world's foremost producer of generic drugs, with many of them destined for US consumers. Teva's stock crashed in the summer of 2017, shortly after the FDA began deregulating. The CEO said that Teva would henceforth be less profitable owing to "greater competition as a result of an increase in generic drug approvals by the U.S. FDA." Yitzhak Peterburg, quoted in Michael Sheetz, "Teva Stock Plummets 18\% after Rough Quarter in US Generic Drug Market," CNBC, August 3, 2017.

${ }^{34}$ FDA, "NDA 22-272 OxyContin Division Director Summary Review for Regulatory Action," December 30, 2009, 10 (emphasis added), https://www.accessdata.fda.gov/drugsatfda_docs/nda/2010/022272s000MedR.pdf.

${ }^{35}$ FDA, "Data and Methods for Evaluating the Impact of Opioid Formulations with Properties Designed to Deter Abuse in the Postmarket Setting: A Scientific Discussion of Present and Future Capabilities," Docket No. FDA-2017-N-2903, July 11, 2017, 182,

https://www.fda.gov/media/107603/download.

${ }^{36}$ FDA, "Data and Methods for Evaluating the Impact of Opioid Formulations," 184.

${ }^{37}$ Abby Alpert, David Powell, and Rosalie Liccardo Pacula, "Supply-Side Drug Policy in the Presence of Substitutes: Evidence from the Introduction of Abuse-Deterrent Opioids," American Economic Journal: Economic Policy 10, no. 4 (2018): 1-35; William N. Evans, Ethan M. J. Lieber, and Patrick Power, "How the Reformulation of OxyContin Ignited the Heroin Epidemic," Review of Economics and Statistics 101, no. 1 (2019): 1-15; and Casey B. Mulligan, "Prices and Federal Policies in Opioid Markets" (NBER Working Paper No. 26812, National Bureau of Economic Research, Cambridge, MA, February 2020a).
} 
lightly regulate prescriptions merely to entice consumers away from heroin, but rather that a cost-benefit analysis should acknowledge all important costs-medical and nonmedical - that result from a regulatory action. As the National Academies of Sciences, Engineering, and Medicine put it, the FDA should "consider the potential effects of these interventions on illicit markets ... and take appropriate steps to mitigate those effects." ${ }^{\text {38 }}$

A fourth example is the "rebate" rule proposed by the Trump administration. ${ }^{39}$ "Rebates" are checks written by drug companies to health insurance plans as part of the competition for plan business and would have been prohibited in the Medicare segment of the prescription drug industry. No market failure was cited, even though OMB Circular A4 specifies that "each agency shall identify ... the failures of private markets or public institutions that warrant new agency action." ${ }^{40}$ It adds that "a particularly demanding burden of proof is required to demonstrate the need for ... price controls." ${ }^{\text {"11 }}$ Although HHS intended the rule to "blow up the way the industry does business" 42 and advertised it as "the most significant change in how Americans' drugs are priced at the pharmacy counter, ever," ${ }^{43}$ it only quantified clerical costs. HHS merely estimated the time it would take for businesspeople to read the rebate rule, to read their own contracts to check for compliance, and perhaps to fill out a form. The cost of the rule was calculated as time spent reading and performing other clerical activities multiplied by the hourly wage rate, which proved to be a mere 0.03 percent of the revenue of the industry segment being regulated. There is nothing smart or evidence based about a cost estimate that ignores how prohibiting

\footnotetext{
${ }^{38}$ Richard J. Bonnie, Morgan A. Ford, and Jonathan K. Phillips, eds., Pain Management and the Opioid Epidemic: Balancing Societal and Individual Benefits and Risks of Prescription Opioid Use (Washington, DC: National Academies Press, 2017), 6.

${ }^{39}$ Department of Health and Human Services, Fraud and Abuse; Removal of Safe Harbor Protection for Rebates Involving Prescription Pharmaceuticals and Creation of New Safe Harbor Protection for Certain Point-of-Sale Reductions in Price on Prescription Pharmaceuticals and Certain Pharmacy Benefit Manager Service Fees, 84 Fed. Reg. 2340 (February 6, 2019). The rule has now been withdrawn for some of the reasons noted in this paper.

${ }^{40} \mathrm{OMB}$, Circular A-4, 4. Circular A-4 is OMB's "guidance to Federal agencies on the development of regulatory analysis" (p. 1).

${ }^{41}$ OMB, Circular A-4, 6 .

${ }^{42}$ Casey B. Mulligan, You're Hired!: Untold Successes and Failures of a Populist President (Washington, DC: Republic Book Publishers, forthcoming 2020c).

${ }^{43}$ Department of Health and Human Services Secretary Alex Azar, quoted in HHS, "Trump Administration Proposes to Lower Drug Costs by Targeting Backdoor Rebates and Encouraging Direct Discounts to Patients," news release, January 31, 2019, https://www.hhs.gov/about/news/2019/01/31/trump-administration-proposes-to-lower-drug-costsby-targeting-backdoor-rebates-and-encouraging-direct-discounts-to-patients.html.
} 
a mechanism of competition (the rebates) might affect competition in the market or might create any other cost beyond paperwork.

In some instances, OMB specifically exempts an agency from estimating costs and benefits of its rules. Regulations issued by the Drug Enforcement Administration in support of the war on drugs are in this category. ${ }^{44} \mathrm{We}$ are not aware of estimates of the prevalence of this type of exemption.

\section{Market Failures and Regulatory Alternatives Are Not Cited}

The fact that the vast majority of new rules is implemented without quantitative estimates of benefits or costs is merely the tip of the iceberg. Another issue is that the quality of analysis itself (for those rules that have an analysis) rarely lives up to the standards set by the government itself. ${ }^{45}$ While estimates of costs and benefits are certainly important elements of a regulatory impact analysis (RIA), several other parts of an RIA are arguably even more important. For example, before even considering benefits and costs, an RIA should assess whether a significant problem exists in the first place and evaluate alternative approaches to solving the problem. Unfortunately, these aspects of RIAs are too often ignored, as shown in the Mercatus Center at George Mason University's Regulatory Report Card project. This project assessed the quality of RIAs accompanying 130 economically significant prescriptive regulations proposed between 2008 and 2013. ${ }^{46}$ Jerry

\footnotetext{
${ }^{44}$ For example, see Schedules of Controlled Substances: Placement of FUB-AMB in Schedule 1, 84 Fed. Reg. 58090, 58094 (October 30, 2019).

${ }^{45}$ See Art Fraas and Randall Lutter, "The Challenges of Improving the Economic Analysis of Pending Regulations: The Experience of OMB Circular A-4," Annual Review of Resource Economics 3, no. 1 (2011): 71-85; Jamie Belcore and Jerry Ellig, "Homeland Security and Regulatory Analysis: Are We Safe Yet?," Rutgers Law Journal 40, no. 1 (2008): 1-96; Robert W. Hahn et al., "Assessing Regulatory Impact Analyses: The Failure of Agencies to Comply with Executive Order 12,866," Harvard Journal of Law and Public Policy 23, no. 3 (2001): 859-71; Robert W. Hahn and Patrick Dudley, "How Well Does the Government Do Cost-Benefit Analysis?," Review of Environmental Economics and Policy 1, no. 2 (2007): 192-211; Robert W. Hahn and Robert Litan, "Counting Regulatory Benefits and Costs: Lessons for the U.S. and Europe," Journal of International Economic Law 8, no. 2 (2005): 473-508; Robert W. Hahn, Randall W. Lutter, and W. Kip Viscusi, Do Federal Regulations Reduce Mortality? (Washington, DC: AEI-Brookings Joint Center for Regulatory Studies, 2000); Government Accountability Office, Regulatory Reform: Agencies Could Improve Development, Documentation, and Clarity of Regulatory Economic Analyses, May 1998; Government Accountability Office, Air Pollution: Information Contained in EPA's Regulatory Impact Analyses Can Be Made Clearer, April 1997.

${ }^{46}$ Prescriptive regulations mandate or prohibit activities. See Jerry Ellig and Patrick A. McLaughlin, "The Quality and Use of Regulatory Impact Analysis in 2008," Risk Analysis 32, no. 5 (2012): 855-80.
} 
Ellig, the lead scholar on this project, reports that 48 percent of these regulations were accompanied by "no significant evidence demonstrating the existence, size, or cause of the problem to be solved," and just 22 percent of the regulations were accompanied by "reasonably thorough evidence showing that a given regulation would likely achieve the desired outcome(s). ${ }^{n 7}$

Even worse, the low quality of analysis is often reflected in poor decision-making in the crafting of the rules that the analyses ostensibly inform. Such poor craftsmanship can occur when an analysis fails to provide evidence that a regulation will solve an actual problem or when it lacks specificity as to the principal cause of a problem. ${ }^{48}$ In 2011, for example, the Securities and Exchange Commission (SEC) adopted a regulation that excludes the value of an investor's primary residence when determining whether the individual meets the $\$ 1$ million net worth requirement to be considered an "accredited investor" who can purchase securities that are not registered with the SEC. The agency also could have considered whether a net worth test is sufficient to protect investors from making bad investment decisions, or whether a financial sophistication test could achieve that objective more effectively. ${ }^{49}$ The SEC conducted no such analyses, so it is not clear whether the regulation solves an actual problem or does so in the most effective way.

There are also regulations that fail to target the principal cause of the problem. In 2015, the FDA finalized a regulation requiring firms that produce, process, pack, or handle animal food to have processes and procedures in place to ensure that animal food is as safe as human food. ${ }^{50}$ The preliminary RIA, conducted while the FDA was developing the regulation, did not even attempt to estimate the benefits or identify their sources. ${ }^{51}$ The final RIA estimated that the regulation would generate $\$ 10.1$ million to $\$ 138.8$ million in benefits annually by protecting humans and pets from contaminated food. The FDA presented no empirical evidence of benefits for livestock, relying instead on a survey of

\footnotetext{
${ }^{47}$ Ellig, "Evaluating the Quality and Use of Regulatory Impact Analysis," 21, 23.

${ }^{48}$ See Patrick A. McLaughlin, Jerry Ellig, and Michael Wilt, "Comprehensive Regulatory Reform” (Mercatus Policy Primer, Mercatus Center at George Mason University, Arlington, VA, 2017).

${ }^{49}$ Jerry Ellig and Hester Peirce, "SEC Regulatory Analysis: A Long Way to Go and a Short Time to Get There," Brooklyn Journal of Corporate, Financial \& Commercial Law 8, no. 2 (2014): 410-11.

${ }^{50}$ FDA, Current Good Manufacturing Practice and Hazard Analysis and Risk-Based Preventive Controls for Food for Animals, 80 Fed. Reg. 56170 (September 15, 2015).

${ }^{51}$ Jerry Ellig and Richard Williams, "FDA's Animal Food Regulation Is for the Birds," Regulation 37, no. 2 (2014): 54-61.
} 
experts who offered their opinions on how effective the rule would be in preventing contamination of livestock feed. ${ }^{52}$ The FDA failed to consider alternative approaches, especially in light of the scant evidence.

Environmental regulations are more likely prepared in accordance with the sound economic principles of Circular $A-4$ because they have more frequently been the subject of lawsuits. The first myth that most regulation is environmental thereby helps contribute to the second myth of smart regulation. Nonenvironmental regulations quantify hardly any of their costs. Even when they do, they get less attention from the administration because they are less likely to be the subject of litigation.

\section{Paternalism with Restrictions Rather Than Advice}

We previously noted how the primary justification of automobile standards was a paternalism aimed at saving consumers from themselves rather than an advisory way of giving them the information they lacked to make their own decisions. Other regulations treat businesses the same way. In 2009, the Department of Transportation's Federal Railroad Administration (FRA) also justified a major public safety rule by asserting that the new regulation would create private business benefits and by including those private benefits in its RIA. ${ }^{53}$ The FRA had been considering requiring railroads to implement automatic train control systems that would prevent collisions since at least 1986, when the National Transportation Safety Board recommended that the FRA implement regulatory standards for a system that would create "positive train separation." 54 The FRA considered doing just that on multiple occasions between 1994 and 2004, but each time it concluded that the costs would far outweigh the benefits.

Even though its estimate of net benefits was negative, the FRA's 2004 analysis changed dramatically from previous versions. ${ }^{55}$ Beginning with the 2004 analysis, the FRA

\footnotetext{
${ }^{52}$ FDA, "Current Good Manufacturing Practice, Hazard Analysis and Risk-Based Preventive Controls for Food for Animals," Final Regulatory Impact Analysis, September 15, 2015, 31-51.

${ }^{53}$ Department of Transportation, Federal Railroad Administration, "Positive Train Control Systems,” Regulatory Impact Analysis, August 3, 2011.

${ }^{54}$ Jerry Ellig and Michael Horney, "Preventing a Regulatory Train Wreck: Mandated Regulation and the Cautionary Tale of Positive Train Control" (Mercatus Working Paper, Mercatus Center at George Mason University, Arlington, VA, June 2016), 6.

${ }^{55}$ Ellig and Horney, "Preventing a Regulatory Train Wreck."
} 
included "business benefits" in its estimate of total benefits that the regulation would create. By contrast, the FRA had issued reports in 1994 and 1999 which mentioned the possibility that positive train control systems could create cost reductions or other benefits for railroads and shippers, but it did not estimate the magnitude of these business benefits or include them in net benefits calculations. The FRA's 2004 analysis claimed that many of these business benefits would accrue to railroads, which the railroads themselves disputed. The FRA's analysis gives a few examples of these hypothetical benefits, including "(1) real-time transmission of locomotive diagnostic information, (2) fuel savings from pacing of trains to avoid cycles of rapid movement followed by long waits, (3) more efficient car use due to frequently updated and optimized dispatching, and (4) avoided investments in track capacity because of more efficient use of existing capacity." Similar to the vehicle emissions rule discussed above, the direct benefits from improving railroad safety only accounted for a very small percentage - about 3 percent —of the total benefits included in the FRA's analysis. The rest of the benefits came from private benefits to railroads (about 28 percent), private benefits to shippers ( 35 to 54 percent, depending on assumptions), and social benefits ( 15 to 34 percent).

The FRA examined positive train control gain following the passage of the Rail Safety Improvement Act of 2008, in which Congress ordered the FRA to promulgate a "positive train control" regulation. In the RIA that accompanied the FRA's final positive train control rule in 2010, private business benefits are not included in the primary analysis, but they are included in a sensitivity analysis. Without including private benefits, the FRA estimated that the costs of implementing a positive train control regulation ( $\$ 9.5$ billion to $\$ 13.1$ billion over a 20 -year period) would far exceed its safety benefits ( $\$ 440$ million to $\$ 674$ million). The FRA's sensitivity analysis, however, concludes that the combination of business benefits and social benefits could lead positive train control to cover its costs in $20-25$ years. $^{57}$

\footnotetext{
${ }^{56}$ Ellig and Horney, "Preventing a Regulatory Train Wreck," 8.

${ }^{57}$ Ellig and Horney, "Preventing a Regulatory Train Wreck."
} 


\section{Myth \#3: The Primary Burden of Regulation Is Paperwork}

The third regulatory myth, reinforced by the other two, is that the main burden of regulation is paperwork. Encouraged by the Paperwork Reduction Act of 1980, federal agencies are comparatively diligent at estimating the clerical work created or saved by their regulations. The clerical costs seem large in an absolute sense: in 2016, OIRA estimated that the public spends about 10 billion hours per year filling out federal forms. ${ }^{58}$ But this estimate refers to all federal rules, not just the new ones. Having looked at many of the federal rules introduced since 2009, we clearly see that paperwork burdens are just the tip of the iceberg in terms of overall costs, but the nonenvironmental regulations rarely include any estimate of the rest of the iceberg. (The 162-page 2016 "overtime rule" from the Department of Labor is an unusual but interesting case, with billions of dollars of paperwork costs, mainly because of a requirement to track work hours for millions of employees who would have otherwise been salaried. ${ }^{59}$ )

We can illustrate the size of paperwork costs compared to economic costs with an example that most people will easily understand - state-issued stay-at-home mandates during the COVID-19 crisis. The paperwork burden associated with these mandates relatively small for an individual: on average, it would require about 12 minutes for an adult to read her governor's executive order containing the stay-at-home decree. At a wage rate of $\$ 25$ per hour, the wages forgone from reading the order are about $\$ 5$ per person. Assuming two people per household need to read the order, the paperwork burden per household is $\$ 10$. In contrast, the economic burden (i.e., the opportunity cost) of complying with the stay-at-home orders is likely to be well into the $\$ 1,000$ s per household. Even if it were only $\$ 1,000$ per household, the paperwork burden would be only $1 / 100^{\text {th }}$ of the economic burden. ${ }^{60}$

\footnotetext{
${ }^{58} \mathrm{OMB}$, Office of Information and Regulatory Affairs, Information Collection Budget of the United States Government, 2016.

${ }^{59}$ Department of Labor, Wage and Hour Division, Defining and Delimiting the Exemptions for Executive, Administrative, Professional, Outside Sales and Computer Employees, 81 Fed. Reg. 32391 (May 23, 2016).

${ }^{60}$ Mulligan (2020b) estimates that the "shutdown" pandemic economy is lacking opportunities worth \$231 per household per day relative to normal activity. Although most of those opportunity costs are "voluntary" (not attributable to state mandates), state mandates need only accelerate the beginning, or delay the end, of the pandemic depression by a total of five days in order to create a cost of more than $\$ 1,000$ per household.
} 
Using the CEA's sample of 18 nonenvironmental regulations, ${ }^{61}$ we estimate that the economic costs of regulation are more than 60 times the clerical costs. These economic costs are, to use the terms of art specified in Circular A-4, "resource costs" and "opportunity costs" of valuable economic activity that cannot occur because of regulation. A prohibition of short-term insurance plans might not require much paperwork but nonetheless could prevent valuable transactions from occurring.

In the CEA sample, the cross-regulation correlation between economic costs and paperwork costs is negative. To be clear, the CEA's sample is intentionally selected to identify economically important regulations. Because the sum of economic costs across all regulations is dominated by the contribution of the costly regulations, the CEA's sample is enough to take seriously the conclusion that the overall total of economic costs far exceeds the overall total of paperwork costs.

Based on its sample, CEA estimated that, in the average year from 2000 to 2016, new regulations added costs of 0.2 percent of national income, including emissions standards. ${ }^{62}$ For 11 years, that is a cumulative increase of about $\$ 3,000$ per household. By comparison, OMB reported that federal paperwork per household in 2015 was about 8.4 hours more than it had been 11 years earlier. ${ }^{63}$ If those 8.4 hours were worth $\$ 50$ each, that would be $\$ 421$ added to the average household's paperwork costs by $2015 .{ }^{64}$ By this metric, only 12 percent of the increase in the per-household burden of regulatory costs can be attributed to paperwork, even though the level of paperwork costs is impressive (10 billion hours per year).

A 2012 final rule by the Centers for Medicare and Medicaid Services mandated that Medicare cover "benzos," which are prescription tranquilizers such as Valium and

\footnotetext{
${ }^{61}$ White House, Economic Report of the President Together with the Annual Report of the Council of Economic Advisers, February 2020.

${ }^{62}$ Treating emissions standards as zero cost, the total added cost is 0.16 percent year, or an 11 year cumulative cost of \$2,400 per household. White House, Economic Report of the President Together with the Annual Report of the Council of Economic Advisers, February 2020, 131. ${ }^{63} \mathrm{OMB}$, Office of Information and Regulatory Affairs, Information Collection Budget of the United States Government. Paperwork increased from 8 billion hours in fiscal year 2004 to 9.78 billion in fiscal year 2015. The number of households increased from 106.588 million to 117.1634 million. See Federal Reserve Bank of St. Louis, "Household Estimates (TTLHHM156N)" (dataset), March 9, 2020, https://fred.stlouisfed.org/series/TTLHHM156N. ${ }^{64}$ US GDP per hour worked in 2015 was about \$65. See Our World in Data, "Productivity per Hour Worked, 1970 to 2017," accessed May 8, 2020, https://ourworldindata.org/grapher/laborproductivity-per-hour-pennworldtable. A significant fraction of GDP per hour worked is capital rather than labor income.
} 
Xanax. ${ }^{65}$ Public commenters had warned the agency that benzos are vulnerable to "misuse and abuse." Because the tranquilizers "enhance" the feeling of opioid consumption, including consumption of heroin and fentanyl, they have been identified in tens of thousands of drug overdoses since the rule went into effect. The costs of that abuse were not even mentioned in the RIA, let alone quantified. ${ }^{66}$ Instead, the only cost counted was the clerical cost because "sponsors will be required to submit information in their formulary files indicating that they will cover these drugs." ${ }^{67}$

Or take the case of the 1915 Seamen's Act's protectionism on behalf of the maritime industry, which contributed to the drowning deaths of 844 people in Chicago. ${ }^{68}$ If the HHS were to conduct a cost-benefit analysis of the Seamen's Act using a similar technique to its analysis of the "benzo" rule, it would estimate a cost for reading the law's 22 pages but estimate no cost for the 844 fatalities! As long as federal rules commonly fail to quantify resource and opportunity costs, there has been no "triumph of the technocrats."

${ }^{65}$ Centers for Medicare and Medicaid Services, Medicare Program; Changes to the Medicare Advantage and the Medicare Prescription Drug Benefit Programs for Contract Year 2013 and Other Changes, 77 Fed. Reg. 22071, 22072 (April 12, 2012).

${ }^{66}$ The RIA notes, but does not quantify, a particular instance of a clerical cost created by the rule. Similarly, the RIA notes, but does not quantify, an expected benefit from improving beneficiary access to these drugs.

${ }^{67} 77$ Fed. Reg. at 22156.

${ }^{68}$ Seamen's Act, Pub. L. No. 63-302, 38 Stat. 1164 (1915). The sinking of the SS Eastland in Chicago on July 24, 1915, is attributed to retrofitting a complete set of lifeboats in order to comply with the new law. The additional weight of the lifeboats made the Eastland so top-heavy that it capsized while passengers were boarding in the Chicago River, causing 844 passengers and crew members to drown. See Susan Q. Stranahan, "The Eastland Disaster Killed More Passengers Than the Titanic and the Lusitania. Why Has It Been Forgotten?," Smithsonian Magazine, October 27, 2014. 


\section{Conclusions}

This paper reaches conclusions about the character and quality of federal regulation using two methods. One method is text analysis of all regulations shown in the Code of Federal Regulations at various points in time. The other method is sampling the flow of regulation based on indicators of economic importance. Both methods contradict three commonly believed myths about federal regulation. The general patterns are also supported in this paper with dozens of specific examples.

First, we find that a small minority of regulation is environmental. By some measures, the flow of new health regulation alone since the year 2000 has far exceeded the flow of environmental regulation. Second, the typical justifications and cost assessments of the nonenvironmental regulations are seriously lacking. Environmental regulations can be the exception to this pattern, which leads us to believe that the first myth about the environmental share of regulation helps sustain the second myth that technocrats have triumphed in the regulatory arena owing to the quality of their analysis. Third, although many regulations create nontrivial paperwork and clerical costs, which are the types of costs most likely to be quantified in RIAs, the vast majority of regulation costs are economic distortions. In many cases, agencies could make important progress toward adhering to the sound economic principles articulated in OMB guidance by engaging in a multiplication operation on numbers already appearing in their RIAs, but currently, agencies are not exerting even this ostensibly trivial effort.

The three myths may be affecting the politics of regulation. In a country that is rich enough for citizens to place significant value on clean air and water, environmental regulations that help correct pollution externalities may have benefits that obviously justify their costs. Influenced by the first myth, it is easy for the public to conclude that regulation generally has benefits that conceivably justify their costs, especially when reassured by the second myth that the regulators are carefully measuring costs and benefits. The special interests seeking protection probably do not mind that their favorite economic regulations are aggregated with truly beneficial environmental ones.

But the costs of special-interest regulations do not stay hidden indefinitely. For example, the share of small businesses citing regulation as their "single most important 
problem" had been increasing through the end of 2016 when it reached 45 percent. ${ }^{69}$ As the costs become visible, a populist backlash against the technocrats may follow, and perhaps deservedly so.

${ }^{69}$ Council of Economic Advisers, The Economic Effects of Federal Deregulation since January 2017, 11 . 


\section{Bibliography}

Alpert, Abby, David Powell, and Rosalie Liccardo Pacula. "Supply-Side Drug Policy in the Presence of Substitutes: Evidence from the Introduction of Abuse-Deterrent Opioids," American Economic Journal: Economic Policy 10, no. 4 (2018): 1-35.

Al-Ubaydli, Omar, and Patrick A. McLaughlin. "RegData: A Numerical Database on Industry-Specific Regulations for All United States Industries and Federal Regulations, 1997-2012," Regulation \& Governance 11, no. 1 (2017): 109-23.

Belcore, Jamie., and Jerry Ellig. "Homeland Security and Regulatory Analysis: Are We Safe Yet?," Rutgers Law Journal 40, no. 1 (2008): 1-96.

Bonnie, Richard J., Morgan A. Ford, and Jonathan K. Phillips, eds. Pain Management and the Opioid Epidemic: Balancing Societal and Individual Benefits and Risks of Prescription Opioid Use (Washington, DC: National Academies Press, 2017), 6.

Broughel, James. "More Information Needed on the Benefits and Costs of Regulations," The Bridge, August 22, 2018.

Centers for Medicare and Medicaid Services, Medicare Program; Changes to the Medicare Advantage and the Medicare Prescription Drug Benefit Programs for Contract Year 2013 and Other Changes, 77 Fed. Reg. 22071, 22072 (April 12, 2012).

Clean Air Act of 1963, 42 U.S.C. $§ 7521(a)(1)(2013)$.

Congressional Budget Office, Federal Subsidies for Health Insurance Coverage for People under Age 65: 2018 to 2028, May 2018.

Council of Economic Advisers, The Administration's FDA Reforms and Reduced Biopharmaceutical Drug Prices, October 2018.

Council of Economic Advisers, The Economic Effects of Federal Deregulation since January 2017: An Interim Report, June 2019.

Crews, Clyde Wayne. "Less Than 1 Percent of Federal Regulations Get Cost-Benefit Analysis," Competitive Enterprise Institute, November 17, 2015, https://cei.org/blog/less-1-percent-federal-regulations-get-cost-benefit-analysis.

Crovitz, Gordon L. “'Economics-Free’ Obamanet,” Wall Street Journal, January 31, 2016. 
Department of Health and Human Services, "Trump Administration Proposes to Lower

Drug Costs by Targeting Backdoor Rebates and Encouraging Direct Discounts to Patients," news release, January 31, 2019, https://www.hhs.gov/about/news/2019/01/31/trump-administration-proposes-tolower-drug-costs-by-targeting-backdoor-rebates-and-encouraging-directdiscounts-to-patients.html.

Department of Health and Human Services, Fraud and Abuse; Removal of Safe Harbor Protection for Rebates Involving Prescription Pharmaceuticals and Creation of New Safe Harbor Protection for Certain Point-of-Sale Reductions in Price on Prescription Pharmaceuticals and Certain Pharmacy Benefit Manager Service Fees, 84 Fed. Reg. 2340 (February 6, 2019).

Department of Labor, Wage and Hour Division, Defining and Delimiting the Exemptions for Executive, Administrative, Professional, Outside Sales and Computer Employees, 81 Fed. Reg. 32391 (May 23, 2016).

Department of Transportation, Federal Railroad Administration, "Positive Train Control Systems," Regulatory Impact Analysis, August 3, 2011.

Ellig, Jerry, and Hester Peirce. "SEC Regulatory Analysis: A Long Way to Go and a Short Time to Get There," Brooklyn Journal of Corporate, Financial \& Commercial Law 8, no. 2 (2014): 410-11.

Ellig, Jerry, and Michael Horney. "Preventing a Regulatory Train Wreck: Mandated Regulation and the Cautionary Tale of Positive Train Control" (Mercatus Working Paper, Mercatus Center at George Mason University, Arlington, VA, June 2016), 6.

Ellig, Jerry, and Patrick A. McLaughlin. "The Quality and Use of Regulatory Impact Analysis in 2008," Risk Analysis 32, no. 5 (2012): 855-80.

Ellig, Jerry, and Richard Williams. "FDA's Animal Food Regulation Is for the Birds," Regulation 37, no. 2 (2014): 54-61.

Ellig, Jerry. "Evaluating the Quality and Use of Regulatory Impact Analysis: The Mercatus Center's Regulatory Report Card, 2008-2013” (Mercatus Working Paper, Mercatus Center at George Mason University, Arlington, VA, July 2016). 
Evans, William N., Ethan M. J. Lieber, and Patrick Power. "How the Reformulation of OxyContin Ignited the Heroin Epidemic," Review of Economics and Statistics 101, no. 1 (2019): 1-15.

Federal Communications Commission, "FCC Opens Office of Economics and Analytics," news release, December 11, 2018, https://docs.fcc.gov/public/attachments/DOC-355488A1.pdf.

Federal Reserve Bank of St. Louis, "Household Estimates (TTLHHM156N)” (dataset), March 9, 2020, https://fred.stlouisfed.org/series/TTLHHM156N.

Food and Drug Administration, "Current Good Manufacturing Practice, Hazard Analysis and Risk-Based Preventive Controls for Food for Animals," Final Regulatory Impact Analysis, September 15, 2015, 31-51.

Food and Drug Administration, "Data and Methods for Evaluating the Impact of Opioid Formulations with Properties Designed to Deter Abuse in the Postmarket Setting: A Scientific Discussion of Present and Future Capabilities," Docket No. FDA2017-N-2903, July 11, 2017, 182, https://www.fda.gov/media/107603/download.

Food and Drug Administration, "Data and Methods for Evaluating the Impact of Opioid Formulations," 184.

Food and Drug Administration, "NDA 22-272 OxyContin Division Director Summary Review for Regulatory Action,” December 30, 2009, 10 (emphasis added), https://www.accessdata.fda.gov/drugsatfda_docs/nda/2010/022272s000MedR.pdf

Food and Drug Administration, Current Good Manufacturing Practice and Hazard Analysis and Risk-Based Preventive Controls for Food for Animals, 80 Fed. Reg. 56170 (September 15, 2015).

Fraas, Art., and Randall Lutter. "The Challenges of Improving the Economic Analysis of Pending Regulations: The Experience of OMB Circular A-4," Annual Review of Resource Economics 3, no. 1 (2011): 71-85.

Government Accountability Office, Air Pollution: Information Contained in EPA's Regulatory Impact Analyses Can Be Made Clearer, April 1997.

Government Accountability Office, Regulatory Reform: Agencies Could Improve Development, Documentation, and Clarity of Regulatory Economic Analyses, May 1998. 
Hahn, Robert W. et al. “Assessing Regulatory Impact Analyses: The Failure of Agencies to Comply with Executive Order 12,866," Harvard Journal of Law and Public Policy 23, no. 3 (2001): 859-71.

Hahn, Robert W., and Patrick Dudley. "How Well Does the Government Do CostBenefit Analysis?," Review of Environmental Economics and Policy 1, no. 2 (2007): 192-211.

Hahn, Robert W., and Robert Litan. "Counting Regulatory Benefits and Costs: Lessons for the U.S. and Europe,” Journal of International Economic Law 8, no. 2 (2005): 473-508.

Hahn, Robert W., Randall W. Lutter, and W. Kip Viscusi. Do Federal Regulations Reduce Mortality? (Washington, DC: AEI-Brookings Joint Center for Regulatory Studies, 2000).

Massachusetts v. EPA, 549 U.S. 497, 532 (2007).

McLaughlin, Patrick A., and Oliver Sherouse. RegData US 3.1 Annual (dataset), QuantGov, Mercatus Center at George Mason University, Arlington, VA, 2018, https://quantgov.org/regdata-us/.

McLaughlin, Patrick A., Jerry Ellig, and Michael Wilt. "Comprehensive Regulatory Reform” (Mercatus Policy Primer, Mercatus Center at George Mason University, Arlington, VA, 2017).

Medicare for All Act of 2019, H.R. 1384, 116th Cong. (2019).

Mulligan, Casey B. "Prices and Federal Policies in Opioid Markets" (NBER Working Paper No. 26812, National Bureau of Economic Research, Cambridge, MA, February 2020a).

Mulligan, Casey B. "Economic Activity and the Value of Medical Innovation during a Pandemic" (NBER Working Paper No. 27060, National Bureau of Economic Research, Cambridge, MA, April 2020b).

Mulligan, Casey B. You're Hired!: Untold Successes and Failures of a Populist President (Washington, DC: Republic Book Publishers, forthcoming 2020c). Office of Management and Budget, “Guidance Implementing Executive Order 13771, Titled 'Reducing Regulation and Controlling Regulatory Costs'” (M-17-21, Executive Office of the President, Washington, DC, April 5, 2017), 6.

Office of Management and Budget, "Guidance Implementing Executive Order 13771,” 6. 
Office of Management and Budget, "Marginal Excess Tax Burden as a Potential Cost under EO 13771,” Regulations.gov, December 6, 2019, https://www.regulations.gov/document?D=OMB-2017-0002-0055.

Office of Management and Budget, "Marginal Excess Tax Burden as a Potential Cost under EO 13771."

Office of Management and Budget, Circular A-4, September 17, 2003.

Office of Management and Budget, Office of Information and Regulatory Affairs, Information Collection Budget of the United States Government, 2016.

Our World in Data, "Productivity per Hour Worked, 1970 to 2017,", accessed May 8, 2020, https://ourworldindata.org/grapher/labor-productivity-per-hourpennworldtable.

Schedules of Controlled Substances: Placement of FUB-AMB in Schedule 1, 84 Fed. Reg. 58090, 58094 (October 30, 2019).

Seamen's Act, Pub. L. No. 63-302, 38 Stat. 1164 (1915).

Selin, Jennifer L., and David E. Lewis. Sourcebook of United States Executive Agencies, 2nd ed. (Washington, DC: Administrative Conference of the United States, 2018), 12.

Sheetz, Michael. “Teva Stock Plummets 18\% after Rough Quarter in US Generic Drug Market," CNBC, August 3, 2017.

Standard Oil Co. of New Jersey v. United States, 221 U.S. 1, 31 S. Ct. 502 (1911).

Stranahan, Susan Q. "The Eastland Disaster Killed More Passengers Than the Titanic and the Lusitania. Why Has It Been Forgotten?," Smithsonian Magazine, October 27, 2014

Sunstein, Cass R. The Cost-Benefit Revolution (Cambridge, MA: MIT Press, 2018), xi, 3. White House, Economic Report of the President Together with the Annual Report of the Council of Economic Advisers, February 2020.

White House, Economic Report of the President Together with the Annual Report of the Council of Economic Advisers, March 2019.

White House, Economic Report of the President Together with the Annual Report of the Council of Economic Advisers, February 2012 